Review Article

\title{
MESUA FERREA LINN. (NAGKESAR): A POTENT ANTIMICROBIAL PLANT SPECIES
}

\author{
SHIFALI THAKUR ${ }^{1}$, HEMLATA KAURAV ${ }^{2}$, GITIKA CHAUDHARY ${ }^{*}$ \\ 1,2,3Shuddhi Ayurveda Jeena Sikho Lifecare Pvt. Ltd. Zirakpur Punjab 140603 \\ Email: shuddhi.research@jeenasikho.co.in
}

Received: 03 May 2021, Revised and Accepted: 25 Jun 2021

\begin{abstract}
Many plants have not been investigated thoroughly, which are used traditionally as a medicine to cure various diseases. Herbal plants play a vital role in the development of new drugs which can be used for various therapeutic indications. Mesua ferrea linn., commonly known as 'Nagchampa' or 'Nagkesar', is one such herbal plant having many potential therapeutic activities. It is used in diseases like rheumatism, asthma, inflammation, fever, dyspepsia, renal diseases, dysentery, bleeding piles, a bacterial and fungal infection. This plant possesses many bioactive chemical constituents like coumarins, xanthones, pyranoxanthones, flavonoids, terpenoids and steroids which can be easily isolated. It can act as precursors on many ailments. These bioactive constituents have many pharmacological activities such as anticancer, antimicrobial, antifungal, anti-inflammatory, anti-arthritis, analgesic, diuretic, anti-hemorrhoid, antiulcer and many more. Almost every part of the plant is reported to have beneficial medicinal properties. But further studies are still needed to explore the pharmacological activities of Mesua ferrea linn. plant so as to gain benefit for the treatment of various diseases. This review highlights the general description, phytochemical profiling, traditional uses and proven pharmacological attributes of Mesua ferrea linn. plant.
\end{abstract}

Keywords: Mesua ferrea, Antimicrobial activity, Nagkesar, Cobra saffron, Ayurveda

(C) 2021 The Authors. Published by Innovare Academic Sciences Pvt Ltd. This is an open access article under the CC BY license (https://creativecommons.org/licenses/by/4.0/)

DOI: https://dx.doi.org/10.22159/ijcpr.2021v13i4.42734 Journal homepage: https://innovareacademics.in/journals/index.php/ijcpr

\section{INTRODUCTION}

Medicinal herbs play a major role in our day-to-day life from providing food, shelter, clothes to medicines. The plants are being in use for medicinal purposes since ancient times. Medicinal plants have beneficial effects on the overall health of humans. As per the reports, Hippocrates used almost 400 different plant species at that times for medical purpose $[1,2]$. In the past times, medicinal preparations were primarily derived from these herbal plants [3]. The plants play a vital role in the traditional medicinal system like Ayurveda, Siddha, Unani, Chinese and Egyptian system [4]. Some plants are greatly promoted due to the associated ethnobotanical belief of different cultures [5]. Many modern drugs in the present era have developed from plant sources because these contains phytochemicals which exhibit various medicinal properties $[6,7]$. Almost half of the modern drugs have the presence of plant contents in them $[8,9]$. WHO is continually promoting the use of herbal drugs as these drugs are considered superior than synthetic drugs because these are easily available, less expensive, compatible action mechanisms inside the living system, multi-target actions and produces negligible side effects [10-14]. One of the most ancient medicinal plant with significant value in many cultures is Mesua ferrea, locally known as Nageswar or Nagkesar. The plant belongs to the Guttiferae family. It is comprised of 47 genera with more than 100 species. The well-known genera of this family are Cratoxylum, Hypericum, Garcina, Mesua and Vismia $[15,16]$ Traditionally various species of Mesua are utilized by the inhabitants of Asian countries for the treatment of a variety of ailments [17, 18]. Mesua ferrea linn. is a medium-sized to a large evergreen tree with a short trunk buttresses at the base. The leaves of the plant are lanceolate, curvaceous, generally with a waxy bloom underneath. The leaves are red in color when mature. Flowers are large, white and fragrant and seeds are dark brown. The leaves and seeds were used as a remedy for cold, fever, sores, scabies by ayurvedic, unani doctors and local kabiraj $[19,20]$. The volatile oil isolated from the flower possesses antifungal and anticancer activities [21-23]. The chemical examination of this plant has been carried out and several constituents were isolated such as ligans, alkaloids, flavonoids, tannins, phthalic acid, gallic acid and terpenoids. The principal constituents of Mesua ferrea linn. include mesuaferrone-A and B mesuaferrol, mesuanic acid, $\alpha$-and $\beta$-amyrin and $\beta$-sitosterol present in stamen [24] while it is also reported that seeds contain essential oils, xanthones and coumarins [25-27]. The plant is widely used in folk remedies for numerous human ailments. Each part of the plant is utilized in various folk remedies of numerous diseases like rheumatism, piles, asthma, ulcers, helminthiasis, dysentery, hemorrhage and many other issues. In Ayurveda, the plant holds a significant place in the treatment of many diseases. Mesua ferrea is also used in herbal formulation to treat piles [28] and cancer [29]. It is also known for shade creation and radiation modification in improving human thermal comfort [30]. Konwer et al., reported that seed oil is a substitute for petroleum gasoline, the fraction distilling between 200 and $300 \mathrm{oC}$ may be used as fuel for diesel engines [31]. In recent years, plenty of research has been conducted to explore the pharmacological activities of the Mesua ferrea plant. Reported studies showed that the plant exhibits important biological properties like antimicrobial, anticancer, antiinflammatory and immunomodulatory etc. Vernacular names and taxonomical classification of the Mesua ferrea linn. are given in table 1 and 2 respectively.

Table 1: Vernacular names of Mesua ferrea linn

\begin{tabular}{ll}
\hline Sanskrit & Kesara, Nagapuspa, Naga, Hema, Gajakesara \\
Hindi & Negkesara, Pila Nagesara \\
English & Cobras Saffron \\
Assam & Naboor, Nahor \\
Farsi & Naremushk \\
Thailand & Bunnak, Bhra ba kaw \\
Phillippine & Kaliuas \\
Malaysia & Penaga \\
Italian & Croco di cobra \\
Arabic & Narae-kaisar \\
Russia & Mezua zheleznaia \\
Chinese & Tie li mu \\
Bihar & Nagkeshur \\
Bengali & Nsgesvara, Nagesar \\
Gujarati & Nagchampa, Nagkesara, Sachunagkeshara, \\
& Pilunagkesar, Tamranagkesar \\
Marathi & Nagkesara \\
Telugu & Nagachampakamu, Kesaramu \\
Tamil & Nangu, Naugaliral, Nagachampakam \\
Kannad & Nagakesari, Nagsampige \\
Assam & Nagakesari, Nahar \\
Andamans & Gangane \\
Malyalam & Nangaa, Nauga, Peri, Nagppu, Nagappovu, Veluthapala \\
Orissa & Nageswar \\
Punjabi & Negeswar \\
Urdu & Narmushk, Nagkesar \\
\hline
\end{tabular}


Table 2: Taxonomical classification of Mesua ferrea linn

\begin{tabular}{ll}
\hline Taxonomical classification & Taxon \\
\hline Kingdom & Plantae \\
Division & Tracheophyta \\
Class & Magnoliopsida \\
Order & Malpighiales \\
Genus & Mesua L. \\
Family & Guttiferae/Calophyllaceae \\
Species & Mesua ferrea \\
Common Name & Nagkesar \\
\hline
\end{tabular}

\section{Botanical description of Mesua ferrea linn}

Mesua ferrea linn. is an evergreen medium to large-sized ornamental plant. It is a medium-sized plant long up to $13 \mathrm{~mm}$, often buttressed at the base with the trunk up to $90 \mathrm{~cm}$ in diameter. Leaves are about 3 to 5 inches long, simple, narrow, ovate and egg-shaped. Leaves are dark green with a whitish underside, the newly growing leaves are red then slowly turn into yellow. Flowers (fig. 1) are about 4 to 7.5 $\mathrm{cm}$ in diameter with four white petals and a center of numerous yellow stamens. Fruits are oblong in shape they are about 2.5 to 5.0 $\mathrm{cm}$ long with persistent calyx. Seeds are dark brown in color and cotyledon is fleshy and oily. The flower, fruit, seeds and leaves of this plant are edible [32].

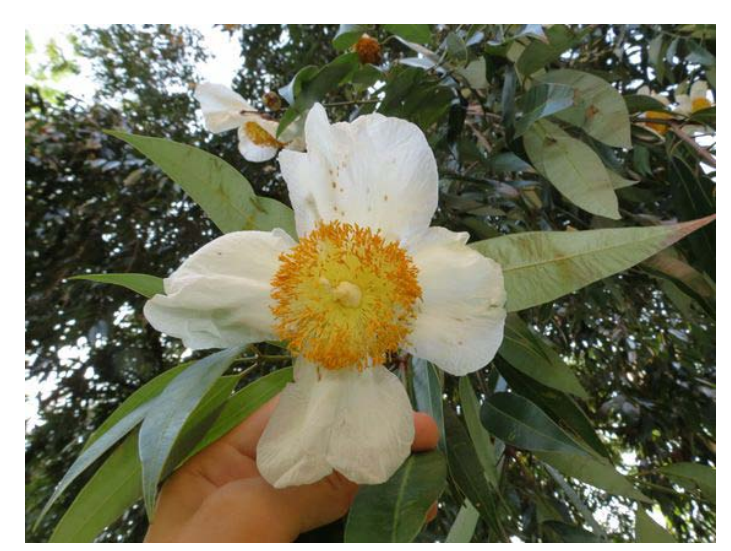

Fig. 1: Mesua ferrea linn. Flower

\section{Geographical distribution of Mesua ferrea linn}

Mesua ferrea linn. is a known native plant in most of the Asian countries including Burma, Cambodia, Indochina, Malaysia, Myanmar, Nepal, Philippines, Sri Lanka, and Thailand. In India, it is distributed in the mountains of Eastern Himalaya and East Bengal, Assam, Burma, Andaman, evergreen rain forests of Western Ghats from South Canara to Travancore [33, 34]

\section{Phytochemical constituents of Mesua ferrea linn}

Kritikar and Rao., reported that the Mesua ferrea is the only species that has been chemically studied from the genus Mesua [35, 36]. Phytochemical studies have revealed plants from this genus to be rich in many classes of secondary metabolites including phenylcoumarins, xanthones and triterpenoides [37-39]. The kernels contain about $75 \%$ of yellowish oil, constituted by the glycerides of common fatty acids like linoleic, oleic, stearic, and arachidic acids. An oil called nahor is extracted from the seeds [40]. 4-Phenylcoumarins like mesuol, mesuagin, mammeisin, mammeigin and mesuone were isolated from seed oil of Mesua ferrea. The trunk bark and heartwood yielded 4-alkylcoumarins ferruols A and B, a lupeol-type triterpenoid guttiferol, mesuaxanthone, 1,5-dihydroxy3-methoxyxanthone, 1-hydroxy-7-methoxyxanthone and $\beta$ sitosterol. Stamens give $\alpha$ and $\beta$-amyrin, $\beta$-sitosterol, bioflavonoidsmesuaferrones A and B, mesuanic acid, 1,5-dihydroxyxanthone, euxanthone 7-methyl ether and $\beta$-sitosterol. Other isolated constituents were mesuaferrol, leuco anthocyanidin, mesuone, euxanthone, etc. Presence of xanthone derivative and essential oil had also been reported from various parts of the plant [41]. Two new yellow pigments, meauxanthone A and memaxantbone B have been isolated from the heart-wood extract of $M$. ferrea. The stamens which yield the drug Nagakeshara contain mesuferrone-A and B, mesuaferrol, mesuanic acid, $\alpha$ and $\beta$-amyrin [42].

\section{Traditional and modern view}

\section{a. Folk view}

There are many social and cultural beliefs associated with some plants representing their rich ethnobotany. Mesua ferrea linn. is one of the rich ethnobotanical plant found in many countries. Rai et al., reported that the plant Mesua ferrea linn. is used in inflammation and septic conditions [43]. This plant was used for its antiseptic, purgative, blood purifier, worm control and tonic properties by the tribes of Assam [44]. In Thai traditional medicine, it is used to treat fever, cold, asthma and as a carminative, expectorant, cardiotonic, diuretic and antipyretic $[45,46]$. The ashes of leaves are utilized for sore eyes. Seeds were used to poultice wounds $[47,48]$. Leaf and flower are antidotes for snakebite and scorpion sting. The fixed oil is used for cutaneous infection, sores, scabies, wounds and rheumatism. The flower is stomachic, expectorant and astringent. The decoction or infusion or tincture of bark and roots is a bitter tonic and useful in gastritis, bronchitis $[49,50]$. The aerial parts are chorionic villus sampling active, spasmolytic, diuretic, abortifacient and used in fever, dyspepsia, renal disorders and in cosmetic [5153]. The local communities of Bangladesh used powder of dried fruits and leaves of Mesua ferrea mixed with ghee to get relief from burning sensation in hands and feet, joint pain and cold [54].

\section{b. Ayurvedic view}

As per Sushruta Samhita (Surgical compendium of Ayurveda), health is a balanced state of Doshas (three biological humors i.e. Kapha (Water and Earth), Pitta (Fire) and Vata (Space and Air), dhatus (seven body tissues), digestion, peace of soul, mind and senses [5557]. Life is not merely to be alive, but to be well and to live a healthy life Ayurveda has mentioned immense herbs, one such amazing herb is Nagkesar. It is also known as Cobra Saffron, Ceylon Ironwood, Indian rose chestnut and Sirunagappu in Ayurveda. It balances the three Doshas of the body. It is considered mainly in bleeding disorders that occur due to the Pitta (heat) imbalance. Nagkesar is mostly indicated in bleeding disorders like piles, menorrhagia, metrorrhagia and epistaxis because it pacifies the Pitta that maintains the heat imbalance. This plant cures excessive bleeding. It also acts as an aphrodisiac and hemostatic. Its main action is on the blood capillaries due to its Kashaya rasa (astringent) and sheet Virya (Cool nature). It also helps to improve the conditions in Metrorrhagia. Metrorrhagia means uterine bleeding at irregular intervals [58-60]. Various parts of Mesua ferrea are utilized either alone or in combination with other medicinal herbs for the treatment of various ailments. Dried flowers have anti-inflammatory and stomachic properties [61]. The bark is traditionally used for the treatment of cough, dysentery, sore throat and vomiting [62]. Mesua ferrea in combination with butter and sugar is prescribed for the treatment of bleeding piles. An Ayurvedic formulation 'Maharishi Amrit Kalash-4' containing Mesua ferrea is traditionally used to treat cancer $[63,64]$. Rasa panchak of Nagkesar is given in table 3.

\section{Table 3: Rasa panchak of Mesua ferrea linn. (Nagakeshara)}

\begin{tabular}{ll}
\hline Sanskrit/English & Sanskrit/English \\
\hline Virya/Potency & Ushana/Hot Potency \\
Vipaka/Metabolic property & Katu/Pungent \\
Guna/Physical Property & Laghu, Ruksha/little, Dry \\
Rasa/Taste & Kashaya, Tikt/Astringent, Bitter \\
\hline
\end{tabular}

\section{Ayurvedic formulations of masua ferrea linn. (Nagakeshara)}

Masua ferrea linn. is present in many Ayurvedic formulations like dasamoolarishta, mahakaleshwara rasa, kanakasava and various churnas which are used for the treatment of many ailments $[65,66]$. 


\section{c. Modern view}

Herbal medicines are primarily known for their negligible adverse impacts and least toxicity than allopathic medicines around the world [67]. But over the past few years, some deliberate practices have been noticed which are majorly responsible for the gradual fall in the quality of herbal products for example adulteration, contamination etc. As per the quality control guidelines of WHO, the definition of adulteration is "herbal material, an herbal constituent or other substance that is either deliberately or non-intentionally (through cross-contamination or contamination) added to an herbal material, herbal preparation, or finished herbal product" [68]. The authenticity and quality of these drugs must be checked carefully as adulterated herbal products have so many health risks associated with them. More checkpoints need to be placed during the whole process from the processing of the raw material to the formation of the end product so that authenticity and quality can be ensured [69, 70]. Some reported studies showed that Mesua ferrea plant is also utilized in modern medicine. Ethanol and petroleum ether extract of Mesua ferrea is used for sore, throat, cough and asthma [71]. The syrup of flower buds is utilized to cure dysentery. The leaves are used in the form of poultice which is applied to the head in severe colds [72, 73]. Based on the scientific studies, Mesua ferrea has the potential to be developed as a polyherbal pharmaceutical product in the form of topical antibacterial gel/cream or as a standardized extract for internal bleeding disorders. Apart from the pharmacological properties, numerous studies have highlighted the industrial applications of Mesua ferrea seed oils as an alternative biofuel in diesel and compression ignition engines. Seed oil is also used in the paint industry, as a multi-purpose industrial coating preparation and as biomaterials. Stamens of the plant are used as fragrant stuffing for cushions and pillows. Wood is considered suitable for all types of heavy construction including railways sleepers, transmission posts, heavy furniture, posts and tool handles $[74,75]$.

\section{Reported therapeutic studies of Mesua ferrea}

Various studies have been conducted on this plant to know its pharmaceutical and therapeutic uses. Large-scale clinical studies are still needed to prove the clinical efficacy of Mesua ferrea against a variety of human ailments. Reported therapeutic and pharmacological uses of Mesua ferrea L. Plant are shown in table 4.

\section{Antioxidant activity}

The anti-oxidant potential of Mesua ferrea L. was evaluated by Prashad et al., in an in vitro study. The ethanol extract of Mesua ferrea leaves was tested for its antioxidant activity by using a test like 2,2-diphenyl-1-picrylhydrazyl (DPPH) free radical scavenging. The findings revealed that $70 \%$ of ethanol extract of Mesua ferrea leaves possess significant antioxidant activity [76]. Another study conducted by Sahu Aalakh and colleagues showed modest antioxidant activity of methanol extract of flowers in DPPH free radical, superoxide and hydrogen peroxide scavenging assays [77]. Teh et al., reported that the polar extract (methanol) of Mesua ferrea roots was more active as compared with less polar and non-polar extracts [78]. Makchuchit et al., reported the promising antioxidant activities of water and hot water extracts of Mesua ferrea flowers in the DPPH scavenging assay. The finding revealed that water extracts of Mesua ferrea flowers possess stronger antioxidant activity than standard agent i.e., butylated hydroxytoluene (BHT) with an EC50 values of 7.49 and $6.95 \mu \mathrm{g} / \mathrm{ml}$ respectively [79]. Rajesh et al., reported that the chloroform and methanol extracts of Mesua ferrea stem bark have good antioxidant activity in the in vitro models. It was found that the extracts protect erythrocytes, hemoglobin and DNA against oxidative stress-induced damage. The finding revealed that methanol extract possesses strong activity as compared with chloroform extract [80]. In another recent study, n-hexane extract of Mesua ferrea stamens has been reported to possess good free radical scavenging activity with an IC50 value of $66.3 \mu \mathrm{g} / \mathrm{ml}$ [81]. Garg et al. investigated that the methanolic extract of dried flowers of Mesua ferrea has antioxidant and hepatoprotective activity in female Wistar mice. An artificial infection was induced by the administration of $S$. aureus in drinking water for $24 \mathrm{~h}$ at the onset of the experiment. The result showed a significant reduction in catalase (CAT), Glutathione (GPX), Glutathione reductase (GR) and Alanine aminotransferase
(ALT) activity. No change was observed in Creatinine phosphokinase (CPK), and creatinine activity in mice [82].

\section{Analgesic activity}

Hassan et al., investigated that the non-polar (n-hexane) fraction of Mesua ferrea leaf have better antinociceptive activity against an acetic acid-induced visceral pain in mouse. The finding revealed that the non-polar fraction possesses better analgesic activity as compared to the polar fraction [83].

\section{Anti-inflammatory activity}

Gopalakrishnan et al., reported that the xanthones i.e., mesuaxanthone-A, mesuaxanthone-B, calophyllin-B, dehydrocycloguanandin, euxanthone, jacareubin and 6-desoxy jacareubin have promising anti-inflammatory activities in carrageenam-induced paw oedema rat models [84]. In addition, an Ayurvedic formulation (Shrishavaleha) containing Mesua ferrea in combination with other herbs has been shown to inhibit oedema development in the carrageenan-induced paw oedema model [85]. Similarly, another recent study reported that $80 \%$ ethanol extract of stem bark of Mesua ferrea have promising anti-inflammatory activity in a variety of in vitro bioassays. Results revealed that ethanol extract at the concentration of 100,200 and $500 \mu \mathrm{g} / \mathrm{ml}$ has stronger anti-inflammatory activity in all in vitro bioassays as compared to the standard drug i.e. Indomethacin [86].

\section{Anti-arthritis activity}

Jalalpure et al., investigated that the seed extract of Mesua ferrea possesses potent anti-arthritis activity in two different in vivo models i.e., Formaldehyde-induced and Complete Freunds's Adjuvant (CFA) induced arthritis in rats. The result showed a reduction in the arthritis lesion by swelling volume in CFA injected paw in rat models [87].

\section{Antispasmodic activity}

An in vitro study was conducted by Prashad et al., for the evaluation of the antispasmodic activity of petroleum extract of Mesua ferrea in the rat ileum. The contraction of the rat ileum was measured on a kymograph. The normal contraction of acetylcholine was reduced up to 70 and $86 \%$ whereas the normal response of acetylcholine in presence of atropine was reduced to $55 \%$ [88].

\section{Antivenom activity}

Uawonggul et al., investigated that the aqueous extract of Mesua ferrea leaves possesses anti-venom activity against fibroblast cell lysis after Heterometrus laoticus scorpion bite. The extract was evaluated against the viability of fibroblast cells after 30 min treatment with mock control or with $0.706 \mathrm{mg} / \mathrm{ml}$ plant extracts pre-incubated with H. laoticus venom. Viability of fibroblast cells after $30 \mathrm{~min}$ treatment with mock control or with 0.706 and $0.406 \mathrm{mg} / \mathrm{ml}$ showed efficiency in protecting against venom-induced lysis [89].

\section{Antimicrobial and antifungal activity}

Antimicrobial activities of different parts of Mesua ferrea have been highlighted by various scientific studies. Verotta et al., investigated that the coumarins (4-alkyl and 4-phenyl 5,7-dihydroxycoumarins) isolated from flower of Mesua ferrea have antimicrobial activity against the strains of gram-positive bacteria [90]. Another study evaluated that the methanol extract of leaves also possesses antimicrobial activities against Basillus species, Escherichia coli, Staphylococcus aurens, Shigella, Salmonella and Lactobacillus arabinosus bacterial strains in the mice $[91,92]$. Ali et al., reported that the polar extract of stem bark of Mesua ferrea have strong antibacterial activity against gram-positive Strptococcus aurens as well as gramnegative Escherichia coli bacterial strains [93]. Likewise, another study revealed the antibacterial efficacy of flower extract of Mesua ferrea against five different strains of Salmonella spp. The extract was found to be active towards all the strains at the concentration of $50 \mu \mathrm{g}$. In addition, flower extract also showed promising in vivo antibacterial activity in S. Typhimurium NCTC 74 challenged mice and caused a statically significant reduction in the viable count of bacterial strain in liver, spleen and heart blood at the dose of $2-4 \mathrm{mg} / \mathrm{mouse}$ [94]. Lim et 
al., reported that the methanol extract of Mesua ferrea seeds has antifungal activities against different strains of fungus including Candida albicans, Trichosporon beigelii, Mucor hiemalis and some other species of Aspergillus [95]. Similarly, a recent study reported that the antibacterial activity of Mesua ferrea seed oil epoxy resin against Klebsiella pneumonia (gram-negative) and Staphylococcus aurens (gram-positive) strains of bacteria [96]. Deshmukh et al., investigated a gel formulation containing six different herbs, including Mesua ferrea. The formulation was found to be beneficial in preventing skin infection associated with resistant strains of Staphylococcus aureus, Pseudomonas aeruginosa and Corynebacterium spp. [97]. Phukan et al., reported that the bio-oils extract of Mesua ferrea has antimicrobial activity against a variety of bacterial and fungal strains, which gives a hint about the possible pharmaceutical application of bio-oils [98].

\section{Water disinfectant activity}

Adewale et al., examined that the seed kernel oil of Mesua ferrea have potent water disinfectant properties and is also used as a natural disinfectant alternative to chlorine. The study showed that kernel oil has remarkable disinfection potential and the kinetic studies suggested that NSKO fitted a first-order model with a k value of 0.040 [99].

\section{Diuretic activity}

Tiwari et al., reported a polyherbal combination (Draksharishta-T and-M) and its marketed formulation comprising of stamens of Mesua ferrea. The formulation was found to induce significant diuretic, kaliuretic and natriuretic effects in the albino rats over $5 \mathrm{~h}$ compared to the control group [100].

\section{Anti-hemorrhoid activity}

Paranjpe et al., evaluated a polyhedral formulation containing Mesua ferrea for its efficacy to treat bleeding piles in a preliminary clinical study using 22 human subjects. The finding revealed that out of 22 subjects, 16 patients showed improvement in terms of bleeding with no noticeable adverse effects [101]. Another recent study also highlighted the efficacy of standardized herbal preparations (Daflon and Roidosanal) containing Mesua ferrea in terms of improvement of ano-rectal conditions in Grade I and II patients [102].

\section{Wound healing activity}

Choudhary et al., reported that the tannins isolated from the ethanol extract of aerial parts of Mesua ferrea have promising wound healing activity in excision and incision wound rat models. The extract was applied in the form of an ointment. Increased epithelialization and wound contraction were found in the animal models [103].

\section{Central nervous system depressant and anticonvulsant activity}

From a reported study, Xanthones (mesuaxanthone-A, mesuaxanthone- $B$, calophyllin- $B$, dehydrocycloguanandin, euxanthone, jacareubin and 6-desoxy jacareubin) were found to have CNS depressant effects in both mouse and rat models. Typical CNS depressant effects i.e., ptosis, sedation, loss of muscle tone and reduced spontaneous motor activity were observed in the xanthones treated animals. Chakma et al., reported that the flower extract of Mesua ferrea has significant anticonvulsant activity in the pentobarbital-induced mouse model [104].

\section{Immunomodulatory and hormone balancing activities}

Chahar et al., studied the effect of mesuol isolated from the seed oil of Mesua ferrea for immunomodulatory activities using both humoral and cellular immune assay. In humoral immune response assay, mesuol was significantly increased the antibody titer values in the rats. In addition, flower extract of Mesua ferrea has also been shown to possess estrogen and progesterone-like effect which were helpful in the correction of hormonal imbalance during menstrual disorders [105].

\section{Antidiabetic activity}

Balekari et al., reported that the methanol extract of Mesua ferrea leaves have promising antidiabetic activity in streptozotocin-induced diabetic rats. It was found that the extract reduced the blood glucose levels and normalized the body weight in diabetic rats [106].

\section{Hepatoprotective activity}

Garg et al., evaluated the hepatoprotective effects of methanol extract of Mesua ferrea flowers in Staphylococcus aureus inoculated male Wistar rats. One weak treatment with 50,100 and $200 \mathrm{mg} / \mathrm{kg}$ of methanol extract showed significant improvement in the levels of liver enzymes like CAT, SOD, GPx and GR with a concomitant decrease in the level of AAT and AST enzymes [107]. In another study, hepatoprotective effects of different extracts of stamens were evaluated using in vitro carbon tetrachloride-induced oxidative stress liver slice culture model. The finding revealed n-hexane and ethanol extracts of stamens protect cultured liver slice cells against carbon tetrachloride-induced oxidative stress [108].

\section{Cardioprotective activity}

A polyherbal drug (Ashwagandharishta) and its marketed preparation containing stamens of Mesua ferrea which have been shown to protect against isoproterenol-induced myocardial infarction in the albino rat model. Treatment with herbal formulation also significantly prevented the isoproterenol-induced adverse changes in the levels of serum marker enzymes such as alanine aminotransferase, aspartate aminotransferase, creatine kinase and lactate dehydrogenase with concomitant improvement in the serum lipid profile. The cardioprotective activity of herbal formulation was due to an increase in in vivo antioxidant level of GSH and inhibition of lipid peroxidation of cardiac membranes in the treated rats [109].

\section{Protection against chronic obstructive pulmonary disease (COPD)}

Rafiq et al., conducted a study in rats. The study showed herbal formulation (Bresol) comprising of Mesua ferrea flowers has protective effects against cigarette smoke-induced COPD in rats. The rats were treated with 250 and $500 \mathrm{mg} / \mathrm{kg}$ for five weeks. The finding revealed improvement in terms of reduction in tracheal inflammation, decrease in TNF- $\alpha$ and total protein levels in the bronchoalveolar lavage fluid and maintained the normal cellular architecture of the trachea and lungs [110].

\section{Anticholinesterase and $\alpha$-amylase inhibitory activity}

Teh and colleagues in their recent study highlighted that the secondary metabolites isolated from different species of Mesua including Mesua ferrea have acetylcholinesterase inhibitory activities and have the potential to be used in Alzheimer's disease [78]. Charabarti et al., revealed that Mesua ferrea extract have moderate $\alpha$-amylase inhibitory activity with an IC50 value of 146.8 $\mu \mathrm{g} / \mathrm{ml}$ while standard drug, acarbose showed strong $\alpha$-amylase inhibitory activity with IC50 value of $14.24 \mu \mathrm{g} / \mathrm{ml}$ [111].

\section{Anticancer activity}

Various crude extracts and pure compounds have shown promising anticancer activities in the preliminary in vitro anticancer screening assays. Volatile oils-rich methanol extract of Mesua ferrea flowers showed strong cytotoxic activities against T-lymphocyte leukemia cells with an IC50 value of $12.5 \mu \mathrm{g} / \mathrm{ml}$ [112]. In another study, ethanol extract of Mesua ferrea flower was tested against three human cancer cell lines viz., CL-6 (cholangiocarcinoma), Hep-2 (Human laryngeal cancer) and Hep G2 (human hepatocarcinoma) cell lines. The result showed that ethanol extract was selectively toxic towards Hep-2 cell line with an IC50 value of $19.22 \mu \mathrm{g} / \mathrm{ml}$ [113]. Another study revealed that essential oil of Mesua ferrea leaves possesses cytotoxic activities against three cancer cell lines viz., KB (oral carcinoma), MCF-7 (breast adenocarcinoma) and NCIH1187 (metastatic lung carcinoma). No toxic effects were found against green monkey normal kidney cell lines [114].

\section{Toxicology}

Acute toxicity studies on different extracts of Mesua ferrea were conducted using albino mouse and rat models. In rat model, $5 \mathrm{~g} / \mathrm{kg}$ doses of three different seed extracts i.e. petroleum ether, ethyl acetate and alcoholic extract did not show any signs of toxicity during the first $24 \mathrm{~h}$ and no mortality in any of the test groups was observed [115]. Likewise, acute toxicity studies of methanol extract 
of Mesua ferrea flowers were performed in Swiss albino mice using three different doses i.e. 50, 500 and $2000 \mathrm{mg} / \mathrm{kg}$. In all the treated groups, none of the mice showed any visible signs of toxicity with zero mortality rates [116]. In another recent study, n-hexane extract of Mesua ferrea stamens has been reported to be safe in the acute toxicity mouse model [117].

Table 4: Reported therapeutic and pharmacological uses of Mesua ferrea L. plant

\begin{tabular}{|c|c|c|c|c|}
\hline S. No. & Extract & Method In vivo/In vitro & Pharmacological activity & Reference \\
\hline 1. & Ethanol Extract & In vitro & Antioxidant & [76] \\
\hline 2. & Methanol Extract & & & [77] \\
\hline 3. & Chloroform and Methanol Extract & & & [81] \\
\hline 4. & Methanolic Extract & Female Wister Rats & & [82] \\
\hline 5. & N-hexane & Mice model & Analgesic & [83] \\
\hline 6. & Xanthones & Rat model & Anti-inflammatory & [84] \\
\hline 7. & Ethanol Extract & In vitro & & [86] \\
\hline 8. & Seed Extract & Rat model & Anti-arthritis & [87] \\
\hline 9. & Petroleum Extract & In vitro & Antispasmodic & [88] \\
\hline 10. & Aqueous Extract & In vitro & Anti-venom & [89] \\
\hline 11. & Coumarins & Gram+Ve strains & Antimicrobial & [90] \\
\hline 12. & Methanolic Extract & Mice Model & Antibacterial & {$[91,92]$} \\
\hline 13. & Polar Extract & Streptococcus aurens and E. coli. & Antibacterial & [93] \\
\hline 14. & Methanol Extract & $\begin{array}{l}\text { Candida albicans, Trichosporon beigelii, } \\
\text { Mucor hiemalis }\end{array}$ & Anti-fungal & [95] \\
\hline 15. & $\begin{array}{l}\text { Polyhedral Formulation containing } \\
\text { stamens of Mesua ferrea }\end{array}$ & Albino rats & Diuretic & {$[100]$} \\
\hline 16. & $\begin{array}{l}\text { Polyhedral Formulation containing } \\
\text { flowers of Mesua ferrea }\end{array}$ & Clinical study & Anti-hemorrhoid & {$[101,102]$} \\
\hline 17. & Ethanol Extract & Rat Model & Wound Healing & [103] \\
\hline 18. & Flower Extract & Rat models & Anticonvulsant & {$[104]$} \\
\hline 19. & Seed oil & Rat models & Immunomodulatory & [105] \\
\hline 20. & Methanol Extract & Diabetic Rats & Antidiabetic & [106] \\
\hline 21. & Methanol Extract & Male Wister Rat & Hepatoprotective & [107] \\
\hline 22. & Stamens Extract & In vitro & & [108] \\
\hline 23. & $\begin{array}{l}\text { Polyhedral Formulation containing } \\
\text { leaves of Mesua ferrea }\end{array}$ & Albino rat model & Cardioprotective & [109] \\
\hline 24. & $\begin{array}{l}\text { Polyhedral Formulation containing } \\
\text { Mesua ferrea plant }\end{array}$ & Rat model & Protection against COPD & [110] \\
\hline 25. & Crude Extract & In vitro & Anticancer & [112] \\
\hline 26. & Ethanol Extract & Human cell line & & [113] \\
\hline
\end{tabular}

\section{CONCLUSION}

The present study is an attempt to provide the detailed information about the medicinal plant, Mesua ferrea L. The reported pharmacological studies indicated that this plant has extraordinary biological potential. It is strongly believed that the present review on the phytomedicinal value of Mesua ferrea, might draw the attention of researchers to use this plant in modern medicines. Apart from medicinal uses it is also being used commercially in polymer industry, painting as firewood and substitute for gasoline. Recent scientific studies have highlighted that Mesua ferrea is a rich source of secondary metabolites which are having multiple health-promoting benefits including antioxidant, anti-inflammatory, antimicrobial, anticancer and many others. Therefore, there is a need to carry out further studies to prove the potential of the plant.

\section{FUNDING}

Nil

\section{AUTHORS CONTRIBUTIONS}

All the authors have contributed equally.

\section{CONFLICT OF INTERESTS}

\section{Declared none}

\section{REFERENCES}

1. Choudhary S, Kaurav H, Chaudhary G. Kasani beej (Cichorium intybus): ayurvedic view, folk view, phytochemistry and modern therapeutic uses. Int J Res Appl Sci Biotechnol 2021;8:114-25.

2. Simmler C, Graham JG, Chen SN, Pauli GF. Integrated analytical assets aid botanical authenticity and adulteration management. Fitoterapia 2018;129:401-14.
3. Ayyanar M, Ignacimuthu S. Ethnobotanical survey of medicinal plants commonly used by Kani tribals in Tirunelveli hills of Western Ghats, India. J Ethnopharmacol 2011;134:851-64.

4. Kumari I, Sudan M, Walia B, Chaudhary G. Zingiber officinale (Ginger): a review based upon its ayurvedic and modern therapeutic properties. Int J Curr Res 2021;13:16583-7.

5. Chauhan SA, Kaur AM, Vyas MA, Khatik GL. Comparison of antidiabetic and antioxidant activity of wild and cultivated variety of Rauwolfia serpentina. Asian J Pharm Clin Res 2017;10:404-6.

6. Chukwuma EC, Soladoye MO, Feyisola RT. Traditional medicine and the future of medicinal Plants in Nigeria. J Med Plants Studies 2015;3:23-9.

7. Lifongo LL, Simoben CV, Ntie Kang F, Babiaka SB, Judson PN. A bioactivity versus ethnobotanical survey of medicinal plants from Nigeria, West Africa. Nat Prod Bioprospecting 2014;4:1-9.

8. Ateș DA, Turgay 0. Antimicrobial activities of various medicinal and commercial plant extracts. Turkish J Biol 2003;27:157-62.

9. Hamburger M, Hostettmann K. Bioactivity in plants: the link between phytochemistry and medicine. Phytochemistry 1991;30:3864-74.

10. Rai LK, Prasad P, Sharma E. Conservation threats to some important medicinal plants of the Sikkim Himalaya. Biological Conservation 2000;93:27-33.

11. Edeoga HO, Okwu DE, Mbaebie BO. Phytochemical constituents of some Nigerian medicinal plants. Afr J Biotechnol 2005;4:685-8.

12. Mann J. Secondary metabolism. Oxford University Press: London; 1978. p. 154.

13. Shanmugam MK, Lee JH, Chai EZ, Kanchi MM, Kar S, Arfuso F, et al. Cancer prevention and therapy through the modulation of transcription factors by bioactive natural compounds. Seminars Cancer Biol 2016;40:35-47.

14. Cragg GM, Newman DJ. Natural product drug discovery in the next millennium. Pharm Biol 2001;39(Suppl):8-17. 
15. Gontijo VS, de Souza TC, Rosa IA, Soares MG, da Silva MA, Vilegas $\mathrm{W}$, et al. Isolation and evaluation of the antioxidant activity of phenolic constituents of the Garcinia brasiliensis epicarp. Food Chem 2012;132:1230-5.

16. Piccinelli AL, Cuesta Rubio O, Chica MB, Mahmood N, Pagano B, Pavone $\mathrm{M}$, et al. Structural revision of clusianone and 7-epiclusianone and anti-HIV activity of polyisoprenylated benzophenones. Tetrahedron 2005;61:8206-11.

17. Teh SS, Cheng Lian Ee G, Mah SH, Lim YM, Rahmani M. Mesua beccariana (Clusiaceae), a source of potential anti-cancer lead compounds in drug discovery. Molecules 2012;17:10791-800.

18. Asif M, Shafaei A, Jafari SF, Mohamed SK, Ezzat MO, Majid AS, et al. Isoledene from Mesua ferrea oleo-gum resin induces apoptosis in HCT 116 cells through ROS-mediated modulation of multiple proteins in the apoptotic pathways: a mechanistic study. Toxicol Lett 2016;257:84-96.

19. Bhide MB, Naik PV, Joshi RS. Bull. Haffkine Inst 1977;5:27-30.

20. Jain SR, Jain MR. Effect of some common essential oils on pathogenic fungi. Plant Med; 1973.

21. Rahman SM, Shabnom S, Quader MA, Hossain MA. Phytochemical study on the ethylacetate extract of the leaves of Mesua ferrea linn. Ind J Chem 2008;8:242-4.

22. Nurdin R, Osman N, Khalid K, Sukari MA. Development of microwave system for extraction of essential oils from Mesua ferrea L. leaves and jasminum sambac flowers. In: International RF and Microwave Conference; 2006. p. 243-6.

23. Rahman SM, Shabnom S, Quader MA, Hossain MA. Phytochemical study on the ethylacetate extract of the leaves of Mesua ferrea linn. Ind J Chem 2008;8:242-4.

24. Subramanyam Raju M, Subba Rao NV. Chemical study of the stamens of Mesua ferrea linn. J Res Imagerie Med 1977;12:124-6.

25. Subramanyam Raju M, Subba Rao NV. Fatty acid composition of nahor (Mesua ferrea Linn) seed oil. J Res Imagerie Med 1977;12:97-9.

26. Banerjee R, Choudhary AR. Mesua ferrea: chemical constituents and biological activity. J Chem Soc Pakistan 1993;15:207-11.

27. Dennis TJ, Akshaya Kumar K. Constituents of Mesua ferrea-a review. Fitoterapia 1998;69:291-304.

28. Sannd R, Bansal P, Bajwa RMS, Acharya MV. Folk medicine of patiala for Arsha (piles). J Ayurveda Health 2004;56:525-9.

29. Palani V, Senthilkumaran RK, Govindasamy S. Biochemical evaluation of antitumor effect of muthu marunthu (a herbal formulation) on experimental fibrosarcoma in rats. J Ethnopharmacol 1999;65:257-65.

30. Konwer D, Baruah K. Refining of the crude oil obtained from Mesua ferrea L. seeds. Chem Ind 1984. p. 413-4.

31. Kallappa M, Hosamani, Savita S, Ganjihal. Unique occurrence of unusual fatty acids in ochrocarpus africanus seed oil. Ind Crop Prod 2003;18:111-6.

32. Lim TK. Edible medicinal and non-medicinal plants. Dordrecht, The Netherlands: Springer; 2012.

33. Kritikar KR, Basu BD. Indian medicinal plants. Vol. 1. $2^{\text {nd }}$ ed. International Book Distributors, Dehradun; 1981. p. 274.

34. Sharma A, Sharma S, Parashar B. Mesua ferrae linn:-a review of the Indian Medical Herb. Systematic Rev Pharm 2017;8:19.

35. Kirtikar KR, Basu BD. Indian medicinal plants. Lalit Mohan Basu. Vol. I-IV. Allahabad, India; 1935. p. 274.

36. Rao RR. Ethnobotanical studies on the flora of Meghalaya-some interesting reports of herbal medicines. In: Jain SK. ed. Glimpses of Indian-Ethnobotany. Oxford and IBH, New Delhi, India; 1981. p. 137-48.

37. Chow YL, Quon HH. Chemical constituents of the heartwood of Mesua ferrea. Phytochemistry 1968;7:1871.

38. Bandaranayake WM, Selliah SS, Sultanbawa MU, Games DE. Xanthones and 4-phenylcoumarins of Mesua thwaitesii. Phytochemistry 1975;14:265-9.

39. Raju MS, Srimannarayana G, Rao NVS, Bala KR, Seshadri TS. Structure of Mesuaferrone-B a new biflavanone from the stamens of Mesua ferrea linn. Tetrahedron Lett 1976;49:4509.

40. Govindchari TR, Pai BR, Suramaniam PS, Ramdas Rao U, Muthukumarswamy N. Constituents of Mesua ferrea L. 11Ferruol a, a new 4-alkylcoumarin. Tetrahedron 1967;23:4161-5.

41. Sharma PC, Yelne MB, Dennis TJ, Joshi A, Billore KV. Database on medicinal plants used in Ayurveda. Bibliography 2000;25:1.
42. Handa SS, Chawla AS, Sharma AK. Plants with antiinflammatory activity. Fitoterapia 1992;63:3-23.

43. Rai LK, Pankaj Prasad, Sharma E. Conservation threats to some important medicinal plants of the Sikkim Himalaya. Biol Conservat 2000;93:27-33.

44. Parukutty B, Chandra GS. "Studies on the medicinal uses of plants by the Boro tribals of Assam-II". J Econ Taxon Bot 1984;5:599-604.

45. Foundation of Resuscitate and Encourage Thai Traditional Medicine. Thai pharmaceutical book. Pikanate Printing Center Cooporation, Bangkok; 2005.

46. Burkill I. A dictionary of the economic products of the malay peninsula. $2^{\text {nd }}$ ed. Ministry of Agriculture and Co-operatives, Kuala Lumpur, Malaysia; 1966.

47. Kumar VP, Chauhan NS, Padh H, Rajani M. Search for antibacterial and antifungal agents from selected Indian medicinal plants. J Ethnopharmacol 2006;107:182.

48. Sahni KC. The Book of Indian Trees. Bombay Natural History Society, Mumbai; 1998.

49. Husain A, Virmani OP, Popli SP, Misra LN, Gupta MM, Srivastava $\mathrm{GN}$, et al. Dictionary of Indian medicinal plants. CIMAP, Lucknow, India; 1992. p. 546.

50. Joy PP, Thomas J, Samuel Mathew, Baby P Skaria. Kerala agricultural university. Arom Med Plant Res 1998. p. 106-7.

51. Nadkarni KM. Indian Materia Medica. Sangam Books Ltd., London; 1976. p. 1319.

52. Santamaría FJ. Diccionario de Mejicanismos, $3^{\text {rd }}$ ed. Editorial Porrua, SA. Mejico, DF Mexico; 1978.

53. Nath D, Sethi N, Singh RK, Jain AK. Commonly used Indian abortifacient plants with special reference to their teratologic effects in rats. J Ethnopharmacol 1992;36:147-54.

54. Sharkar P, Rahman MM, Haque Masum GZ, Nayeem MA, Hossen MM, Azad AK. Ethnomedicinal importance of the plants in villages in kushtia sador and mirpur upozila, bangladesh. J Herbs Spices Med Plants 2013;19:401-17.

55. Torwane NA, Hongal S, Goel P, Chandrashekar BR. Role of Ayurveda in management of oral health. Pharmacogn Rev 2014;8:16.

56. Hankey A. CAM modalities can stimulate advances in theoretical biology. J. Evidence Based Complementary Altern Med 2005;2:5-12.

57. Lad V. The human constitution. Ayurveda: The science of selfhealing. Lotus Press: Wilmot; 1985. p. 26-36.

58. Muddgal D. Dravyagun Vijnana. Ayurvedic hindi pustak bhandar. $2^{\text {nd }}$ edition; 2019.

59. Sharma PV. Dravyagun Vigyan. Chaukambha Bharti Academy, Varanasi; 2019.

60. Sivarajan VV, Balachandran I. Ayurvedic drugs and their plant sources. Oxford and IBH publishing; 1994./Sivarajan VV, Balachandran I. Ayurvedic drugs and their plant sources. In: Mohan P. editor. Oxford7 IBH Publishing Co. Pvt. Ltd; 1994.

61. Ratnamhin A, Elliott S, Wangpakapattanawong P. Vegetative propagation of rare tree species for forest restoration. Chiang Mai J Sci 2011;38:306-10.

62. Keawsa-ard S, Kongtaweelert S. Antioxidant, antibacterial, anticancer activities and chemical constituents of the essential oil from Mesua ferrea leaves. Chiang Mai J Sci 2012;39:455-63.

63. Saxena A, Dixit S, Aggarwal S, Seenu V, Prashad R, Bhushan SM, et al. An ayurvedic herbal compound to reduce toxicity to cancer chemotherapy: a randomized controlled trial. Indian J Med Paediatr Oncol 2008;29:11-8.

64. Asif M, Jafari SF, Iqbal Z, Revadigar V, Oon CE, Majid ASA, et al. Ethnobotanical and phytopharmacological attributes of mesua ferrea: a mini-review. J Appl Pharm Sci 2017;7:242-51.

65. Nishteshwar K, Vidyanath. Sahasra yogam. $2^{\text {nd }}$ ed. Chaukhamba Sanskrit series office, Arishta prakarana. Varanasi 2008;5:227.

66. Das G, Sastri A. Bhaishajya ratnavali (Vidyodini Hindi vyakhya). Chaukhambha sanskruta sanskruta samsthan. kasa chikitsa, Varanasi 2001;15:320-1.

67. Agarwal A. Critical issues in quality control of herbal products. Pharma Times 2005;37:9-11.

68. Simmler C, Graham JG, Chen SN, Pauli GF. Integrated analytical assets aid botanical authenticity and adulteration management. Fitoterapia 2018;129:401-14. 
69. Wallace LJ, Boilard SM, Eagle SH, Spall JL, Shokralla S, Hajibabaei M. DNA barcodes for everyday life: routine authentication of natural health products. Food Res Int 2012;49:446-52.

70. Thakur S, Kaurav H, Chaudhary G. Terminalia arjuna: a potential ayurvedic cardio tonic. Int J Res Appl Sci Biotechnol 2021;8:227-36.

71. Singhe WM, Selliah BS, Uvais MS, Sultanbawa S. Xanthones and 4-phenyl coumarins of Mesua thwaitessi. Phytochemistry 1975;14:265-9.

72. Bala KR, Seshadri TR. Isolation and synthesis of some coumarin components of Mesua ferrea seed oil. Phytochemistry 1971;10:1131-4.

73. Sharma PC, Yelne MB, Dennis TJ. Database on medicinal plants used in ayurveda. C. C. R. A. S. Department of Indian systems of medicine and homeopathy (ISM and H), ministry of health and family welfare, government of India; 2002. p. 187, 315, 391, 478.

74. Lim TK. Edible medicinal and non-medicinal plants. New York: Springer; 2012.

75. Dabi M, Saha UK. Implications of blended Mesua ferrea linn oil on performance, combustion and emissions of compression ignition diesel engines. Thermal Sci Eng Prog 2020;19:100579.

76. Prasad DN, Rao BG, Rao ES, Rao TM, Praneeth DVS. Quantification of phytochemical constituents and in vitro antioxidant activity of Mesua ferrea leaves. Asian Pac J Trop Biomed 2012;2:S539-S42.

77. Sahu Alakh N, Hemalatha S, Sairam K. Quantitative phytochemical and heavy metal estimation of Mesua ferrea flowers and Argyreia speciosa leaves. Int J Pharm Sci Rev Res 2013b;22:276-8.

78. Teh S, Ee G, Mah S, Yong Y, Lim Y, Rahmani M, et al. In vitro cytotoxic, antioxidant, and antimicrobial activities of Mesua beccariana (Baill.) Kosterm., Mesua ferrea linn., and Mesua congestiflora extracts. Biomed Res Int 2013;2013:5170-2.

79. Makchuchit S, Itharat A, Tewtrakul S. Antioxidant and nitric oxide inhibition activities of Thai medicinal plants. J Med Assoc Thai 2010;93(Suppl 7):S227-35.

80. Rajesh KP, Manjunatha H, Krishna V, Kumara Swamy BE. Potential in vitro antioxidant and protective effects of Mesua ferrea linn. bark extracts on induced oxidative damage. Ind Crops Prod 2013;47:186-98.

81. Barbade KD, Datar AG. Extraction, bioactivities, phytochemical investigation and in vivo toxicity studies of Mesua ferrea L. Stamens. Int J Pharm Pharm Sci 2015;7:93-7.

82. Garg S, Sharma K, Ranjan R, Attri P, Mishra P. In vivo antioxidant activity and hepatoprotective effects of methanolic extract of Mesua ferrea linn. Int J PharmTech Res 2009;1:1692-6.

83. Hassan MT, Ali MS, Alimuzzaman M, Raihan SZ. Analgesic activity of Mesua ferrea linn. Dhaka Univ J Pharm Sci 2006;5:73-5.

84. Gopalakrishnan C, Shankaranarayanan D, Nazimudeen SK, Viswanathan S, Kameswaran L. Anti-inflammatory and C. N. S. depressant activities of xanthones from calophyllum inophyllum and Mesua ferrea. Indian J Pharmacol 1980;12:181-91.

85. Yadav SS, Galib, Ravishankar B, Prajapati PK, Ashok BK, Varun B. Anti-inflammatory activity of Shirishavaleha: an ayurvedic compound formulation. Int J Ayurveda Res 2010;1:205-7.

86. Ranganathaiah $\mathrm{P}$, Hanumanthappa $\mathrm{M}$, Venkatarangaiah $\mathrm{K}$. Evaluation of in vitro anti-inflammatory activity of stem bark extracts of Mesua ferrea linn. Int J Pharm Pharm Sci 2016;8:173-7.

87. Jalalpure SS, Mandavkar YD, Khalure PR, Shinde GS, Shelar PA, Shah AS. Antiarthritic activity of various extracts of Mesua ferrea linn. seed. J Ethnopharmacol 2001;138:700-4.

88. Prasad DN, Basu SP, Srivastava AK. Antispasmodic activity of the crude and purified oil of Mesua ferrea seed. Anc Sci Life 1999;19:74-5.

89. Uawonggul N, Chaveerach N, Thammasirirak N, Arkaravichien T, Chuachan C, Daduang S. Screening of plants acting against Heterometrus laoticus scorpion venom activity on fibroblast cell lysis. J Ethnopharmacol 2006;103:201-7.

90. Verotta L, Lovaglio E, Vidarib G, Finzib PV, Neric MG, Raimondic A, et al. 4-Alkyl-and 4-phenyl coumarins from Mesua ferrea as promising multidrug-resistant bacteria. Phytochemistry 2004;65:2867-9.
91. Mazumder R, Dastidar SG, Basu SP, Mazumder A, Kumar S. Emergence of Mesua ferrea linn. leaf extract as a potent bactericide. Ancient Sci Life 2003;22:160-5.

92. Mazumder R, Dastidar SG, Basu SP, Mazumder A. Effect of Mesua ferrea linn. flower extract on Salmonella. Indian J Exp Bio 2005;43:566-8

93. Ali MA, Sayeed MA, Bhuiyan MSA, Sohel FI, Yeasmin MS, Antibacterial screening of cassia fistula and Mesua ferrea. J Med Sci 2004;4:24-9.

94. Mazumder R, Dastidar SG, Basu SP, Mazumder A, Singh SK. Antibacterial potentiality of Mesua ferrea linn. flowers. Phytother Res 2004;18:824-6.

95. Lim TK. Edible medicinal and non-medicinal plants. New York: Springer; 2012.

96. Das G, Kalita RD, Gogoi P, Buragohain AK, Karak N. Antibacterial activities of copper nanoparticle-decorated organically modified montmorillonite/epoxy nanocomposites. Appl Clay Sci 2014;90:18-26.

97. Deshmukh P, Gupta P, Shankar R. In vitro and in vivo efficacy of a herbal formulation against skin infections. J Pure Appl Microbiol 2009;3:199-204.

98. Phukan MM, Chutia RS, Kumar R, Kalita D, Konwar BK, Kataki R. Assessment of antimicrobial activity of bio-oil from pongamia glabra, Mesua ferrea and parachlorella spp deoiled cake. Int J Pharm Bio Sci 2013;4:P910-8.

99. Adewale AI, Mirghani MES, Muyibi SA, Daoud JI, Abimbola MM. Disinfection studies of Nahar (Mesua ferrea) seed kernel oil using pour plate method. Afr J Biotechnol 2011;10:18749-54.

100. Tiwari P, Patel RK. Evaluation of the diuretic potential of draksharishta prepared by traditional and modern methods in experimental rats. Pharmacologyonline 2011;3:566-72.

101. Paranjpe P, Patki P, Joshi N. Efficacy of an indigenous formulation in patients with bleeding piles: a preliminary clinical study. Fitoterapia 2000;71:41-5.

102. Aggrawal K, Satija N, Dasgupta G, Dasgupta P, Nain P, Sahu AR. Efficacy of a standardized herbal preparation (Roidosanal) in the treatment of hemorrhoids: A randomized, controlled, open-label multicentre study. J Ayurveda Integr Med 2014;5:117-24.

103. Choudhary GP. Wound healing activity of the ethanolic extract of Mesua ferrea linn. Int J Adv Pharm Biol Chem 2012;1:369-71.

104. Chakma TK, Khan MTH, Rahman T, Choudhuri MSK, Rajia S, Alamgir M. Screening of bangladeshi medicinal plants for their effects on pentobarbital-induced sleeping time in mice. Ars Pharm 2006;47:211-7.

105. Chahar M, Kumar DS, Lokesh T, Manohara K. In vivo antioxidant and immunomodulatory activity of mesuol isolated from Mesua ferrea L. seed oil. Int Immunopharmacol 2012;13:386-91.

106. Balekari U, Veeresham C. Insulinotropic activity of methanolic extract of mesua ferrea linn. J Basic Appl Sci 2015;11:410-7.

107. Garg S, Sharma K, Ranjan R, Attri P, Mishra P. In vivo antioxidant activity and hepatoprotective effects of methanolic extract of Mesua ferrea linn. Int J PharmTech Res 2009;1:1692-6.

108. Rajopadhye AA, Upadhye AS. Hepatoprotective effect of stamen extracts of Mesua ferrea L. against oxidative stress induced by CCl4 in liver slice culture model. Nat Prod Sci 2012;18:76-82.

109. Tiwari P, Patel RK. Cardioprotective activity of ashwagandharishta on isoproterenol-induced myocardial infarction. Pharmacologyonline 2012;1:17-24.

110. Rafiq M, Viswanatha GL, Suryakanth DA, Azeemuddin M, Jagadeesh M, Dhanush $\mathrm{K}$, et al. Poly-ingredient formulation Bresol® ameliorates experimental chronic obstructive pulmonary disease (COPD) in rats. Sci Pharm 2013;81:833-42.

111. Chakrabarti R, Singh B, Prakrith VN, Vanchhawng L, Thirumurugan K. Screening of nine herbal plants for in vitro $\alpha$ amylase inhibition. Asian J Pharm Clin Res 2014;7:84-9.

112. Nordin A, Ahmad FBH, Taufiq Yap YH, Ali AM. Volatile components of methanol extract from the flower of malaysian musea ferrea linn. Orient J Chem 2004;20:69-72.

113. Mahavorasirikul W, Viyanant V, Chaijaroenkul W, Itharat A, Na-Bangchang K. Cytotoxic activity of Thai medicinal plants against human cholangiocarcinoma, laryngeal and hepatocarcinoma cells in vitro. BMC Complement Altern Med 2010;28:10-55. 
114. Keawsa-ard S, Liawruangrath B, Kongtaweelert S. Bioactive compounds from Mesua ferrea stems. Chiang Mai J Sci 2015;42:185-95.

115. Jalalpure SS, Mandavkar YD, Khalure PR, Shinde GS, Shelar PA, Shah AS. Antiarthritic activity of various extracts of Mesua ferrea linn. seed. J Ethnopharmacol 2001;138:700-4.
116. Udayabhanu J, Kaminidevi S, Thangavelu T. A study on acute toxicity of methanolic extract of Mesua ferrea L. in swiss albino mice. Asian J Pharm Clin Res 2014;7:66-8.

117. Barbade KD, Datar AG. Extraction, bioactivities, phytochemical investigation and in vivo toxicity studies of Mesua ferrea L. stamens. Int J Pharm Pharm Sci 2015;7:93-7. 